\title{
Strengthening Religious Literacy During the Pandemic
}

\author{
Sari Narulita ${ }^{1}$, Rihlah Nur Aulia ${ }^{2}$, Amaliyah $^{3}$, and Andy Hadiyanto ${ }^{4}$ \\ \{sari-narulita@unj.ac.id ${ }^{1}$, rihlah-nuraulia@unj.ac.id ${ }^{2}$, amaliyah@unj.ac.id ${ }^{3}$, andy-hadiyanto@unj.ac.id $\left.{ }^{4}\right\}$ \\ Islamic Religious Education $\mathrm{UNJ}^{1,2,3,4}$
}

\begin{abstract}
Indonesia is a religious country where religious beliefs become guidelines for behaviour. A person's religious beliefs can be seen from his response to this pandemic in the current pandemic period. Misunderstandings in religion can produce different answers. This study aims to describe what side strengthening can be done to increase religious literacy during this pandemic. The method used in this research is the descriptive analysis method with data collection techniques through observation, questionnaires, and interviews. The findings from the study show that it is necessary to strengthen religious literacy during this pandemic so that they can respond adequately without having to endanger themselves or those around them
\end{abstract}

Keywords: Religious literacy; Islamic Religious Education; Pandemic

\section{Introduction}

Indonesia is a religious country, based on research in 2020, which revealed that Indonesia is in the top rank or is the most religious country. $96 \%$ of Indonesian respondents think one must believe in God to be moral, and 98\% consider religion necessary in their lives. Compared to previous years, the level of Indonesian people's belief in God and religion is also not much different. During 2007-2019, the idea that faith makes a person moral was shared by $96-99 \%$ of respondents - making Indonesia always occupy the top rank as the country with the most religious citizens. (Pew Research Center 2020). Religion is influential in all walks of Muslim's life. (Hadiyanto et al. 2020).

Religion should foster peace. A study revealed that faith would make life more directed, give peace, increase religious belief, avoid bad behaviour, and increase tolerance. (Haryanto 2017) These results strengthen the understanding of the Qur'an sura Ra'd verse 28, which explains that people who believe will be able to calm the heart through remembering Allah. Remember Allah is implemented by doing all His commands and staying away from His prohibitions.

Understanding and tranquillity in religion is a challenge during the pandemic. This condition is caused by special requirements, which make it challenging to practice religious habits. The massive spread of Covid-19 is prone to occur in crowds. This fact has made the government make a policy prohibiting crowds; this impacts the prohibition of carrying out mass activities, including praying in congregations in mosques, holding majlis taklim (informal religious learning), or just doing istighotsah (praying together for asking some needs). Another policy that makes worship different is the obligation to wear a mask when praying. The MUI, as a representation of the ulama, also set a fatwa that supports the 
government's policies. Unfortunately, the existing policies are challenging to implement; when some consider these policies to hinder the implementation of worship; They assume that the policy is contrary to the text of religious teachings they understand. This textual understanding is strengthened by understanding those who only understand religion through social media; without re-verifying the religious information it receives. Information that is not following the existing conditions forms wrong information and shapes the religious behaviour of its readers. (Ulya 2018)

This difference in perspective makes ordinary people confused. Religion no longer makes a person calm, but it went awry. Especially when some people are still determined to pray in the congregation without heeding Health protocols; and eventually trigger a new cluster, a mosque cluster.

Because of that, it is necessary to strengthen religious literacy, understanding that it does not just understand religion textually; but also see its relevance contextually. This article aims to show strengthening where literacy can be done so that activities can be directed at understanding the religion well. Finally, Muslims can be calmer in carrying out their lives, especially in this emergency moment.

Religious literacy is the ability to see and analyze the intersection between religion and social, political, and cultural life. Religiously literate people will understand history, central texts, beliefs, and practices of religious traditions born in specific social, historical, and cultural contexts. (Moore 2015). Having religion means building a relationship with God and His creatures. Faith understands its teachings textually and contextually. Religion is inseparable from the practice of community life. (Dinham, Francis, and Shaw 2017)

Moore revealed the low level of religious literacy in several countries (Indonesia, India, Pakistan, and the United States). The quality of understanding one's religious literacy affects the religious behaviour of its adherents. He saw that some Americans' development of Islam phobia was caused by the low religious literacy about Islam and the spiritual practice itself. Moore called this phenomenon religious illiteracy or "religious illiteracy." On the other hand, the strengthening of extremism, radicalism, and intolerance in some Muslim societies is related to their low religious literacy towards Islam itself. (Moore 2015).

\section{Findings and Discussion}

Religious literacy ability is the ability to see and analyze the correlation between spiritual teachings and social, political, and cultural life through various perspectives. Religious literacy presupposes several things: first, a fundamental understanding of the central texts that are the core of spiritual teachings, history, and contemporary manifestations of religious traditions formed according to specific social, political, and cultural contexts. Second is the ability to see and explore various political, social, and cultural expression dimensions of religion in a particular space and time. (Dinham and Francis 2015). through religious literacy, one is required to understand religion textually and understand it contextually.

Understanding of religion is textually understood through the text of written religious teachings; this is only understood through understanding the primary language of Islamic instruction -Arabic language- and how to use it. At the same time, the textual understanding refers to establishing Shari'a law, and it is Maqashid Syariah or the protection of five essential things in human life, which are take care of religion, soul, mind, descendants, and property. Keeping these five things can be done by maintaining things that perpetuate their existence or prohibiting things that can endanger their existence. (Syatar, Amiruddin, and 
Rahman 2020).

An understanding of the verses of the Qur'an and hadith without being accompanied by a contextual interpretation will only produce a rigid version. This understanding does not correspond to the primary purpose of the emergence of the verse or hadith. For example, the hadith that encourages Muslims to enliven the mosque, narrated by Anas bin Malik that the Prophet said, 'Indeed if Allah sends down a disease from the sky to the people of the earth then God keeps the disease away from those who enliven mosque."

The above hadith seems to encourage Muslims to continue to revitalize the mosque, even in a pandemic. Various studies reveal that the hadith is a hadith with a weak level due to a defect in the chain so that it cannot be used as a basis for behaviour. Muslims should refer to other hadiths with a sahih level, which is more worthy of reference, such as the hadith of Usamah bin Zaid who stated that the Prophet said: "Tha'un (epidemic of infectious diseases) is a warning from God to test His servants from among the people. So, when you hear that the plague is spread in a land, do not enter it. And when the curse is distributed in the land where you are, do not flee from it. " (HR Bukhari and Muslim).

The hadith is in line with the current state of emergency, which is to take care of the souls of Muslims becomes vulnerable when each other cannot take care of themselves properly. A Muslim should be a person who does not harm himself and does not harm others.

In the face of a pandemic, the public's panic makes their immunity lower and makes them more vulnerable to being exposed to covid-19. The dilemma that exists is caused by the large number of people being exposed and even causing death. In a state of fear, man will draw closer to God; but in fact, they feel shackled in their freedom of worship. They have no space to be able to pour out all their worries and complaints. The State University of Jakarta created the UNJ Sehat program to overcome panic from various aspects. Several teams are provided, including a group of doctors, psychologists, sportsmen, and spiritual health. The last team actively conducts religious literacy improvement programs every week, whether referring to the contextual understanding of the Islamic law or how Islamic teachings direct their followers to respond to a disaster.

The UNJ Sehat Program, especially Spiritual Health, aims to increase religious literacy to apply religion in real life optimally. Moreover, this pandemic is a time when all religious studies can be easily accessed. The endless flow of digital information and the ease of accessing data makes one need to sort data on the internet. Ability in media literacy allows internet users to anticipate things that are the effects of internet exposure. (Rastati 2018)

Openness to a variety of information in cyberspace will help strengthen religious literacy in the Muslim community. But it can also put the Muslim community in a vulnerable position to misunderstanding when the Muslims get information from sources that cannot be valid. Besides the need for media literacy skills, religious criticality is also needed. (Jannah and Narulita 2019)

The Spiritual Health webinar program is paralleled with the Spiritual Health consultation activity. During the consultations, we found out that some of the problems commonly encountered include how to worship optimally during a pandemic and deal with people who think corona is just a setting; Is it legal to pray by wear a mask? How to deal with people who judge people and do not motivate exposed patients? and so forth.

Through a questionnaire to participants who participate in the Spiritual Health webinar every week, most get spiritual peace, especially when the event begins with reciting Quran and reading shalawat (praise to the Prophet) together. They also argue that the material presented is relevant by current conditions, especially regarding how to respond to this pandemic condition with patience and humility and make this pandemic period an 
opportunity to learn religion for the better, which is not only textual oriented also contextually. Religious literacy is not just understanding religion alone; but also make it a basis for thinking and behaving. (Kadi 2020)

\section{Conclusion}

Strengthening religious literacy is done by providing textual understanding that is aligned with the context. Contextual understanding can be done by understanding the initial purpose of establishing Islamic law to cover five main things: religion, soul, mind, nasb (descendants), and property. The ability to understand the arguments of the Koran and hadith contextually makes it easier for us to understand the reasons for making government policies. The government sets a policy to pray using a mask and do it at a distance to maintain the safety of ourselves and those around us.

\section{Acknowledgements}

The author would like to thank the UNJ Sehat Team, the Spiritual Health team, and the Islamic Religious Education Department colleague who provided time, space, energy, and thoughts to succeed in religious literacy among students. The author also appreciates the State University of Jakarta, which has provided financial support in organizing activities and supporting this research.

\section{Reference}

[1] Dinham, Adam and Matthew Francis. 2015. Religious Literacy in Policy and Practice. Bristol: Policy Press. Bournemouth University.

[2] Dinham, Adam, Matthew Francis, and Martha Shaw. 2017. "Towards a Theory and Practice of Religious Literacy: A Case Study of Religion and Belief Engagement in a UK University." Religions 8(12):276.

[3] Hadiyanto, Andy, M. Ridwan Effendi, Sari Narulita, and Firdaus Wajdi. 2020. Pendidikan Agama Islam Untuk Perguruan Tinggi. Jakarta: Fikra Publika.

[4] Haryanto, Handrix Chris. 2017. "Apa Manfaat Dari Agama? (Studi Pada Masyarakat Beragama Islam Di Jakarta).” Insight: Jurnal Ilmiah Psikologi 18(1):19.

[5] Jannah, Miftahul and Sari Narulita. 2019. "The Islamic Conservatism in Education." Pp. 175-82 in International Conference On Islam And Muslim Societies (ICONIS) 2019.

[6] Kadi, Titi. 2020. "Literasi Agama Dalam Memperkuat Pendidikan Multikulturalisme Di Perguruan Tinggi.” Jurnal Islam Nusantara 04(01):81-90.

[7] Moore, Diane L. 2015. "Overcoming Religious Illiteracy: A Cultural Studies Approach." World History Connected 4(1):1-14.

[8] Pew Research Center. 2020. The Global God Divide.

[9] Rastati, Ranny. 2018. "Media Literasi Bagi Digital Natives: Perspektif Generasi Z Di Jakarta.” Kwangsan: Jurnal Teknologi Pendidikan (Vol 6, No 1 (2018): Kwangsan):60.

[10] Syatar, Abdul, Muhammad Majdy Amiruddin, and Arif Rahman. 2020. "Darurat Moderasi Beragama Di Tengah Pandemi Corona Virus Desease 2019 (Covid-19)." 
KURIOSITAS: Media Komunikasi Sosial Dan Keagamaan 13(1):1-13.

[11] Ulya, Ulya. 2018. "Post-Truth, Hoax, Dan Religiusitas Di Media Sosial." FIKRAH (Vol 6, No 2 (2018): December 2018):283-302. 